\title{
Cytoskeletal Genes Regulation by Chronic Morphine Treatment in Rat Striatum
}

\author{
Cynthia Marie-Claire ${ }^{*,}$, Cindie Courtin', Bernard P Roques' and Florence Noble' \\ 'Departement de Pharmacochimie Moleculaire et Structurale, Universite Rene Descartes-Paris V, Paris, France
}

\begin{abstract}
It has been previously suggested that morphine can regulate the expression and function of some proteins of the cytoskeleton. In the present study, we used real-time quantitative polymerase chain reaction to examine the effects of chronic morphine administration, in rat striatum, on 14 proteins involved in microtubule polymerization and stabilization, intracellular trafficking, and serving as markers of neuronal growth and degeneration. Chronic morphine treatment led to modulation of the mRNA level of seven of the 14 genes tested. Glial fibrillary acidic protein (Gfap) and activity-regulated cytoskeleton-associated protein (Arc) mRNA were upregulated, while growth associated protein (Gap43), clathrin heavy chain (Cltc), $\alpha$-tubulin, Tau, and stathmin were downregulated. In order to determine if the regulation of an mRNA correlates with a modulation of the expression of the corresponding protein, immunoblot analyses were performed. With the exception of Gap43, the levels of Cltc, Gfap, Tau, stathmin, and $\alpha$-tubulin proteins were found to be in good agreement with those from mRNA quantification. These results demonstrate that neuroadaptation to chronic morphine administration in rat striatum implies modifications of the expression pattern of several genes and proteins of the cytoskeleton and cytoskeletonassociated components.

Neuropsychopharmacology (2004) 29, 2208-22I5, advance online publication, 16 June 2004; doi: I 0. I 038/sj.npp. I 3005 I 3
\end{abstract}

Keywords: cytoskeleton; morphine; neuronal plasticity; gene expression

\section{INTRODUCTION}

There is increasing evidence that morphine alters gene expression in different areas of the brain, even following a single injection. Acute morphine administration induces modification of the expression of genes involved in processes as diverse as signal transduction coupled to $\mu$ opioid receptors (Fan et al, 2002, 2003; Kaewsuk et al, 2001; Przewlocka et al, 1994), transcription factors (ErdtmannVourliotis et al, 1998; Kelz et al, 1999), and calcium binding proteins (Tirumalai and Howells, 1994). Interestingly, an analysis of the gene expression profile following a single injection of morphine revealed that one of the major groups of altered genes in the rat medial striatum consisted of cytoskeleton-related proteins (Loguinov et al, 2001). Morphine has been shown to induce neuronal changes that persist for a long time following cessation of drug exposure (Nestler and Aghajanian, 1997). However, the molecular and cellular mechanisms underlying these long-lasting changes are still not fully understood.

*Correspondence: Dr C Marie-Claire, Departement de Pharmacochimie Moleculaire et Structurale, CNRS FRE 2463, Universite Rene Descartes-Paris V, 4, Av de l'Observatoire, 75006 Paris, France,

E-mail: marie@pharmacie.univ-paris5.fr

Received 8 October 2003; revised 13 May 2004; accepted 18 May 2004

Online publication: 19 May 2004 at http://www.acnp.org/citations/ Npp05190403462/default.pdf
Nevertheless, the most interesting results, which are expected to have functional implications in the long-lasting effects of morphine, are those obtained following chronic treatment. An increase in dynamin expression after chronic morphine treatment has been shown in mice striatum (Noble et al, 2000). This protein has a key role in receptor endocytosis and is able to interact with microtubules, actin cytoskeleton, and the mitogen-activated protein kinase signalling pathway (review in Sever, 2002). Among the remarkable changes observed following repetitive administration of morphine, a reduction in the size of dopaminergic neurons in the ventral tegmental area and a decrease in dendritic branching and spine density in the cerebral cortex and nucleus accumbens have been reported (Sklair-Tavron et al, 1996; Robinson and Kolb, 1999). Consistent with these morphological changes, the expression and function of neurofilament proteins are altered by chronic morphine treatment in the ventral tegmental area in rats (BeitnerJohnson et al, 1992; Beitner-Johnson and Nestler, 1993). Alterations of neurofilaments have also been found in the prefrontal cortex of human opioid addicts (Garcia-Sevilla et al, 1997; Ferrer-Alcon et al, 2000). Moreover, a decrease in the volume of frontal cortex of male opioid-dependent patients has been reported by Pezawas et al (1998). Taken together, these results suggest that opiates may induce neuronal damages in humans, and that the modifications observed in rat models are pertinent to the investigation of this problem, thought to be the basis of morphine addiction. 
We therefore investigated the mRNA and protein expression levels of several cytoskeletal or cytoskeletal-associated proteins in rat striatum after repeated administration of increasing doses of morphine. This was achieved by combining real-time quantitative RT-PCR and immunoblot analyses. Markers of neuronal plasticity like growthassociated protein-43 (Gap43) and activity-regulated cytoskeleton-associated protein (Arc); of intracellular traficking, like dynamin, clathrin heavy chain (Cltc) and filamin $\alpha$ (Flna) or of microtubule assembly and stabilization like, $\alpha$ tubulin, stathmin, Stop, and Tau were chosen. Since active interactions between neuron and glia are important for synaptogenesis and synaptic plasticity (review in Bacci et al, 1999), we also studied glial fibrillary acidic protein (Gfap), a marker of astroglial cells. Modulations of mRNA and proteins levels were observed following chronic morphine administration supporting the hypothesis of a relationship between cytoskeleton modifications and long-lasting actions of morphine.

\section{MATERIALS AND METHODS}

\section{Animals and Drug Treatment}

Male Sprague-Dawley rats (IFFA CREDO, France) weighing $180-200 \mathrm{~g}$ at the beginning of the experiments were used. Experiments were performed according to the European Communities Council Directive (86/609/EEC). Animals were housed under controlled conditions $(12 \mathrm{~h}$ alternating light/dark cycle at $21 \pm 1^{\circ} \mathrm{C}$ ) and had free access to food and water. Saline and morphine (Francopia, France) were injected i.p. twice daily. Morphine was progressively increased from 10 to $40 \mathrm{mg} / \mathrm{kg} / \mathrm{dose}$. The first and second number inside parentheses represent the dose of morphine $(\mathrm{mg} / \mathrm{kg})$ injected at 0900 and 1900 hours, respectively, on consecutive days: first day $(10,20)$, second day $(20,40)$, third day through fifth day $(40,40)$ as previously described (Noble et al, 2000). The animals were killed by decapitation on the morning of the sixth day, $16 \mathrm{~h}$ after the last injection. This time point was chosen on the basis of previous studies using a similar protocol showing that the significant behavioral signs of spontaneous withdrawal appear $24 \mathrm{~h}$ after the last morphine injection (Ruiz et al, 1996). Different animals were used for real-time PCR analysis and immunoblotting. The striata were rapidly dissected on ice and frozen in isopentane at $-50^{\circ} \mathrm{C}$ and stored at $-80^{\circ} \mathrm{C}$ until use.

\section{RNA Isolation and Real-Time PCR Analysis}

Total RNA was extracted from individual striatum with RNABle reagent (Eurobio, France) following the manufacturer's protocol. The quality of total RNA was assessed by agarose gel and quantified by spectophotometry. RNA was reverse transcribed in a final volume of $20 \mu$ containing $1 \times$ RT-PCR buffer ( $3 \mathrm{mM} \mathrm{MgCl}_{2}, 75 \mathrm{mM} \mathrm{KCl}$, and $50 \mathrm{mM}$ Tris$\mathrm{HCl}$ ( $\mathrm{pH} 8.3)$ ), $500 \mu \mathrm{M}$ each deoxynucleotide triphosphate, $20 \mathrm{U}$ of RNasin RNase inhibitor (Promega, France), $10 \mathrm{mM}$ DTT, $100 \mathrm{U}$ of Superscript II RNase $\mathrm{H}^{-}$reverse transcriptase (Invitrogen, France), $1.5 \mu \mathrm{M}$ random hexamers (AmershamPharmacia, France), and $1 \mu \mathrm{g}$ of total RNA. Samples were incubated at $20^{\circ} \mathrm{C}$ for $10 \mathrm{~min}$ and $42^{\circ} \mathrm{C}$ for $30 \mathrm{~min}$, and reverse transcriptase was inactivated by heating at $99^{\circ} \mathrm{C}$ for $5 \mathrm{~min}$ and cooling at $5^{\circ} \mathrm{C}$ for $5 \mathrm{~min}$. PCR primers were chosen with the assistance of Oligo 6.42 software (MedProbe, Norway). The primer nucleotide sequences used in this study are listed in Table 1. Fluorescent PCR analysis was performed using a LightCycler ${ }^{\mathrm{TM}}$ instrument (Roche Diagnostics, France). The cDNAs were diluted 40 -fold and $5 \mu \mathrm{l}$ were added to the PCR reaction mix to yield a total volume of $10 \mu \mathrm{l}$. The PCR reagents were obtained from the FastStart DNA Master SYBR Green I kit (Roche Diagnostics, France). The reaction buffer contained $4 \mathrm{mM} \mathrm{MgCl}_{2}$ and $0.5 \mu \mathrm{M}$ of each primer. Amplification protocols consisted of $35-40$ cycles of denaturation at $94^{\circ} \mathrm{C}(5 \mathrm{~s})$, annealing at $68^{\circ} \mathrm{C}$ $(5 \mathrm{~s})$, and extension at $72^{\circ} \mathrm{C}(10 \mathrm{~s})$. Fluorescent signals were obtained once in each cycle by sequential-fluorescence

Table I Primer Sequences Used for SYBR Green-Based Real-Time Quantitative Polymerase Chain Reaction

\begin{tabular}{lll}
\hline Gene & Forward primer & Reverse primer \\
\hline Tbp & TGCACAGGAGCCAAGAGTGAA & CACATCACAGCTCCCCACCA \\
Flna & TGGCCCAGCCTTCCATTACTG & GCCCCCCTCTCCTGCATC \\
Gap43 & GATGCGGCCCCTTCAGAG & CCTTGGCTGGGCCATCTT \\
Gfap & CAGAAGCTCCAAGATGAAACCAA & TCTCCTCCTCCAGCGACTCAAC \\
Tau & ACCATGGCTTAAAAGCTGAAGAAG & CGGCCACTCGAGCTTGAGTC \\
Snca & TGGGCAAGGGTGAGAAG & TAGGCTTCAGGCTCATAGTCT \\
Stathmin & CCGGGAGGCGCAAATG & TTGTTCTTCCGCACCTCTTCA \\
Cltc & ATCGCCCAGCTGTGTGAGAA & CCACTCGGGGTTGAGAAGATG \\
Stop & GCGTGGCCGTGCATCACTAG -tubulin & CGGGCAACTGCATCCGACT \\
Fos & TTGAGCGCCCAACCTACACT & TCAGGGCCCCATCAAATCT \\
Dynamin-1 & GGCAAAGTAGAGCAGCTATCTCCT & TCAGCTCCCTCCTCCGATTC \\
Arc & CTTGCGGGGACCAGAACAC & GGCATGGGCGTGCTGAC \\
Synphilin-1 & GCCGCCAAACCCAATGTGA & GTCGCCCGTGGGCACATAG \\
\hline
\end{tabular}


monitoring of each sample tube at the end of extension. cDNAs from a naive rat brain were used to generate an external standard curve for each gene. We also quantified transcripts of the gene coding for the TATA-binding protein (Tbp), a component of the DNA-binding protein complex TFIID, as the endogenous RNA control and normalized each sample on the basis of its Tbp content as previously described (Bieche et al, 2000).

\section{Immunoblotting}

Rat striata were homogenized in lysis buffer containing $10 \mathrm{mM}$ Tris- $\mathrm{HCl} \mathrm{pH}$ 7.5, $50 \mathrm{mM} \mathrm{NaCl}, 30 \mathrm{mM}$ sodium pyrophosphate, $1 \mathrm{mM}$ DTT, $5 \mu \mathrm{M} \mathrm{ZnCl}_{2}, 1 \%$ triton, $50 \mathrm{mM}$ $\mathrm{NaF}, 0.5 \mathrm{mM}$ PMSF, $100 \mu \mathrm{M}$ sodium orthovanadate, $5 \mathrm{nM}$ okadaic acid, and Complete ${ }^{\mathrm{TM}}$ protease inhibitor complex (Roche Diagnostics, France). Homogenates were centrifuged at $4{ }^{\circ} \mathrm{C}, 15 \mathrm{~min}$ at $15000 \mathrm{~g}$, and the supernatants were used. The protein concentration of samples was determined using Bradford reagent (Sigma, France) and bovine serum albumine (BSA) as a standard. Protein extracts were resolved by SDS-polyacrylamide gel electrophoresis and immunoblotted with primary antibody. The antibodies used were Gfap $(1: 2000)$, Gap43 $(1: 2000)$, and Tau $(1: 2000)$ from Chemicon (France); $\beta$-actin $(1: 10000)$ and $\alpha$-tubulin $(1: 10000)$ from Sigma (France); Stathmin $(1: 20000)$ from Calbiochem (France); Clathrin $(1: 1000)$ and $\operatorname{Arc}(1: 250)$ from BD Biosciences (France); Dynamin (1:6000) from Upstate (UK). Secondary antibodies were anti-mouse and anti-rabbit horseradish peroxidase-linked antibody (1:20000) from Amersham Bioscience (France) and antigoat horseradish peroxidase-linked antibody $(1: 20000)$ from Jackson Immunoresearch (France). Immunoreactive protein bands were detected by enhanced chemiluminescence reagents (ECL; Amersham Pharmacia Biotech, France) on an X-ray film. Protein expression was quantified using Bio1D software (Vilber Lourmat, France).

\section{Statistical Analyses}

All series of data were analysed with GraphPad Prism ${ }^{\circledR}$ software. Results are displayed as mean \pm SEM of 4-6 animals. Statistical analyses were performed using Student's test. The level of significance was chosen as $P<0.05$.

\section{RESULTS}

\section{Modulation of the mRNA Levels of Several Genes by Chronic Morphine Treatment in Rat Striatum}

Using the real-time quantitative RT-PCR method, we investigated expression modulation in 14 cytoskeletalrelated genes by chronic morphine administration (Figure 1). The expression levels of two immediate-early genes were assessed. The mRNA level of the immediateearly gene Fos was not affected by chronic morphine treatment. On the contrary, the immediate-early gene Arc was significantly upregulated by chronic morphine treatment (1.48-fold). Two genes involved in clathrin-coated pit formation were analyzed. Cltc mRNA level was significantly downregulated (1.4-fold) in morphine-treated rats, while that of dynamin showed a slight but not significant increase.
The expression levels of actin and of one of its associated proteins, Flna, were not affected by chronic morphine treatment. The expression levels of two proteins involved in the formation of cytoplasmic inclusions, Snca and Synphilin-1, were not affected in the striatum of rats chronically treated with morphine, as compared to control animals. The mRNA level of four genes involved in microtubules polymerization, stabilization, and depolymerisation were analyzed. A significant decrease was observed in three of them: stathmin, $\alpha$-tubulin, and Tau (1.53-, 1.56and 1.42-fold, respectively) following chronic morphine treatment, while the expression level of the microtubule stabilizer Stop was not altered under these conditions. Chronic morphine treatment led to a significant increase of the mRNA level of the astroglial specific marker Gfap in the striatum (1.41-fold) as compared to control animals. The mRNA level of the neuronal growth cones marker Gap43 was significantly decreased in morphine-treated rats (1.42fold). In order to determine if regulation of the mRNA level of these genes by chronic morphine could lead to regulation of the expression of the corresponding proteins and thus to have a functional impact, immunoblot analyses were performed.

\section{Modulation of the Expression of Proteins by Chronic Morphine Treatment in Rat Striatum}

The expression of $\beta$-actin protein was not modified in this treatment (Figure 2); therefore, this protein was used as a control of loading for each lane. As expected, the previously observed increase or decrease in mRNA levels previously observed reflect modifications of the corresponding proteins. Thus, as shown in Figure 2, Gfap and Arc immunoreactivity were increased in rats chronically treated with morphine as compared to control animals (1.77- and 2.33-fold, respectively). Moreover, while only a slight insignificant increase of dynamin mRNA level was observed, an upregulation of protein immunoreactivity was obtained (1.97-fold). In the case of tubulin, Tau, stathmin and Cltc, the downregulation was confirmed at the protein level (1.36-, 1.66-, 1.3-, and 1.43-fold, respectively). Surprisingly, the regulation of Gap43 mRNA and protein were not in agreement. While a significant decrease of the mRNA level was observed, the protein expression was significantly upregulated (1.3-fold).

\section{DISCUSSION}

The aim of this study was to examine the effects of chronic morphine treatment on gene expression for neuronal and glial cytoskeleton components, using quantitative real-time RT-polymerase chain reaction and immunoblot. The striatum was selected owing to its high level of $\mu$ opioid receptors and its role in morphine-induced behavioral sensitization involved in the establishment of an addiction state (Maisonneuve et al, 1992). Moreover, it has been shown that morphine administration increases the activity of dopaminergic neurons in substantia nigra pars compacta and increases dopamine release in the striatum (Walker et al, 1987; Pozzi et al, 1995). Samples were collected $16 \mathrm{~h}$ following the last morphine injection. It has been shown 
Arc

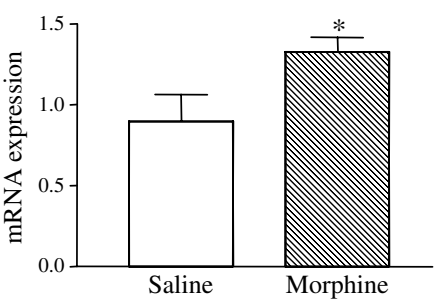

Flna

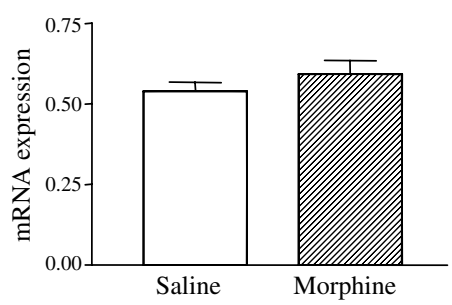

Gfap

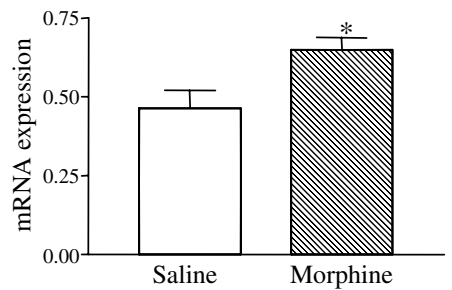

$\alpha$-tubulin
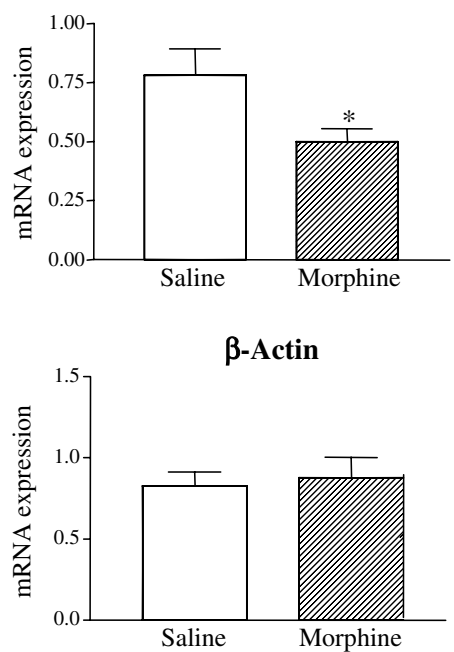

Fos

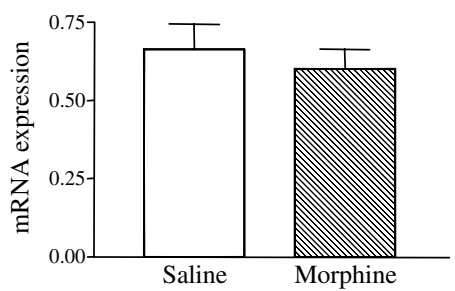

Snca

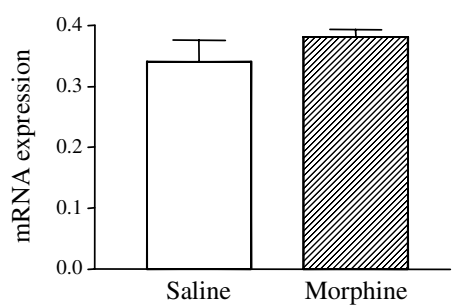

Cltc

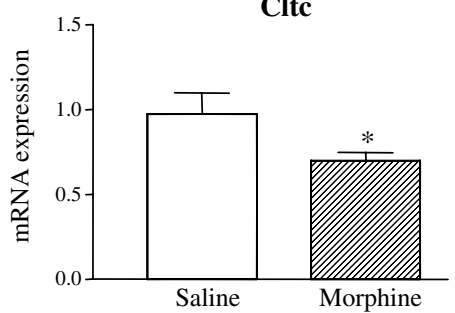

Dynamin
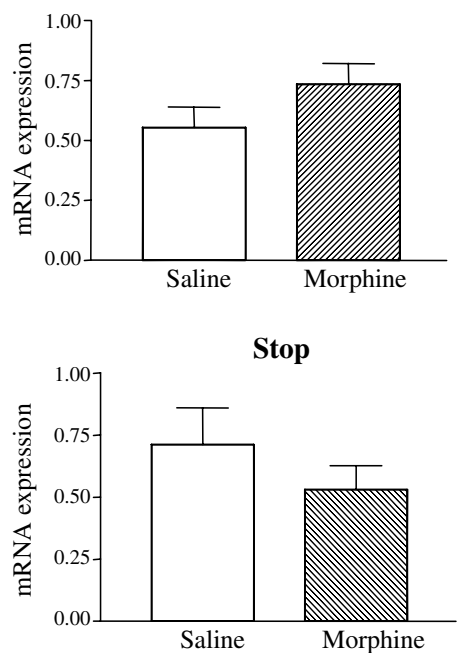

Gap43

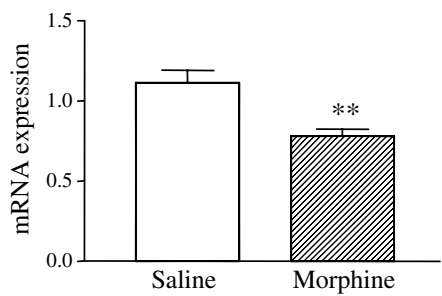

Synphilin
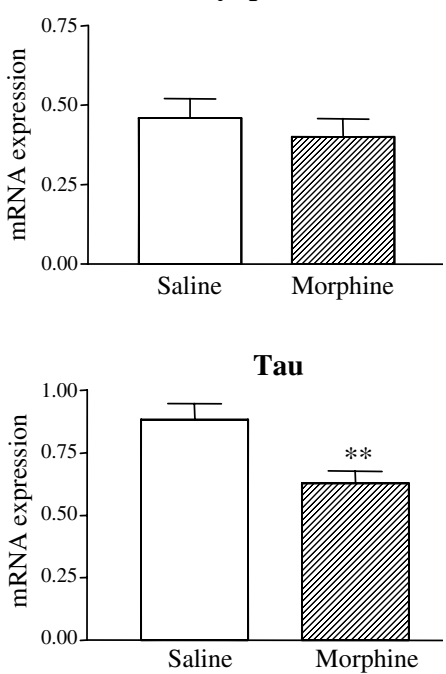

Stathmin

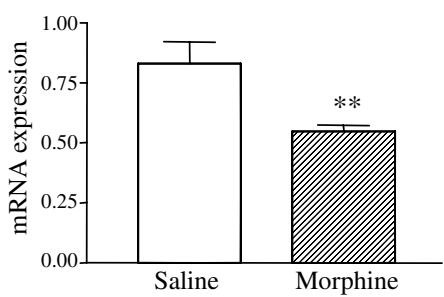

Figure I Effect of chronic treatment (5 days) with morphine on the mRNA level of cytoskeletal genes by real-time RT-PCR analysis. All data have been normalized for levels of Tbp expression within the same sample and represent mean \pm SD ( $n=6-8$ rats), *P<0.05, **P<0.0 (Student's test).

that with this protocol the behavorial signs of spontaneous withdrawal appear $24 \mathrm{~h}$ after the last injection and the maximum severity of abstinence appears $36 \mathrm{~h}$ after the last dose of morphine (Ruiz et al, 1996). Moreover, the modifications reported, at the biochemical level, after spontaneous withdrawal from chronic morphine treatment are observed $24 \mathrm{~h}$ after the last morphine injection (Bassareo et al, 1995; Crippens and Robinson, 1994; Diana et al, 1995). The modulation of protein expression observed here is thus more likely to represent an adaptation of the neuronal cytoskeleton to chronic morphine treatment, but we cannot exclude a contribution by the mild withdrawal experienced at this time point by the animals.

In accordance with previous results (Noble et al, 2000), we observed that an upregulation of dynamin protein expression and a slight but insignificant increase of 

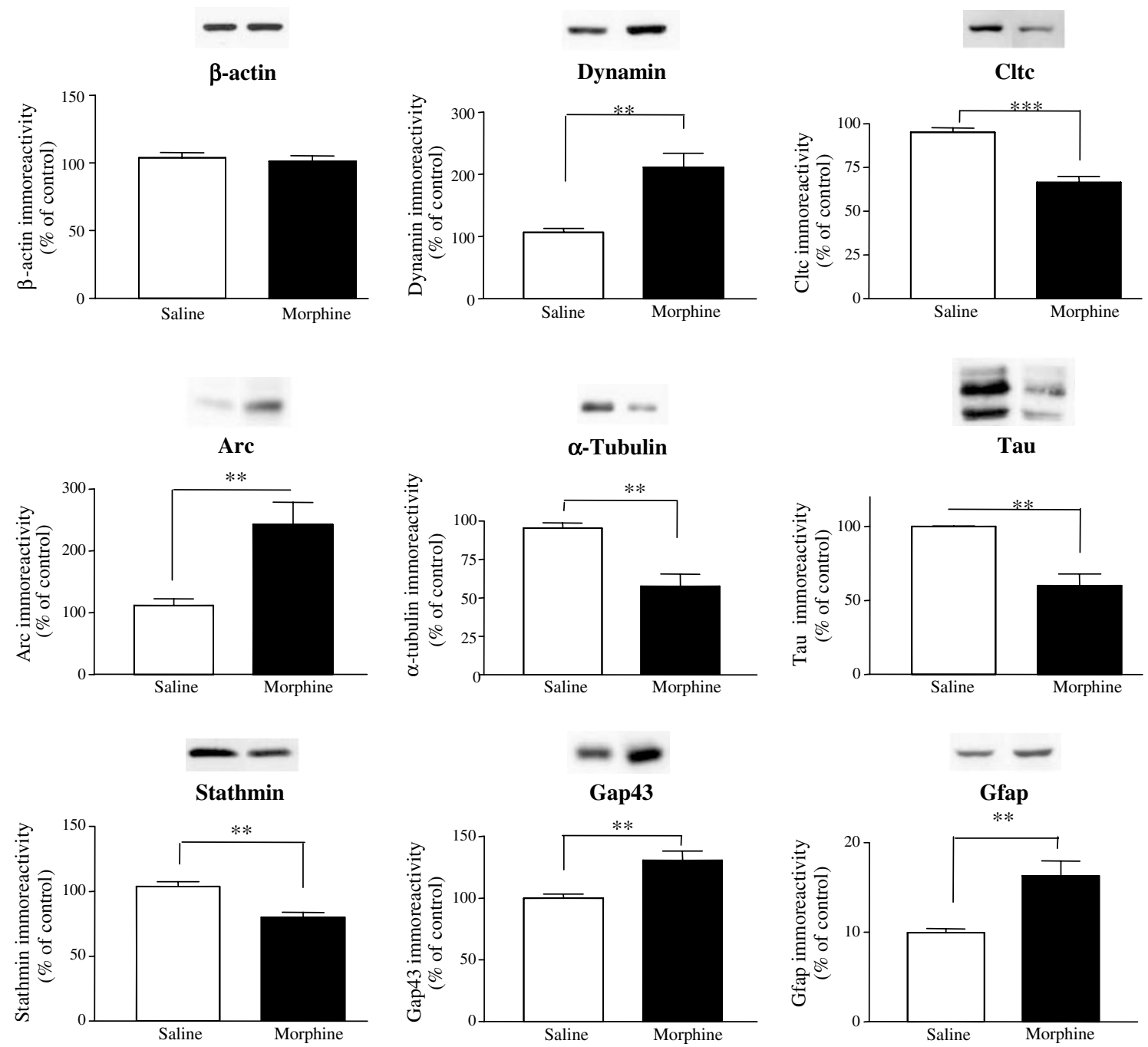

Figure 2 Effect of chronic treatment with morphine on the expression level of the tested proteins by immunoblot analysis. Columns are means \pm SD ( $n=5-6$ rats) and expressed as percentage of saline treated rats. Representative immunoblots are presented above each graph. $* P<0.05, * * P<0.01$, **** $P<0.00$ I (Student's test).

dynamin mRNA was induced by chronic morphine treatment. Dynamin forms rings around the necks of clathrin-coated pits and is required for the excision of the vesicle from the plasma membrane. This process is important for receptor recycling (review in Sever, 2002). Interestingly, the expression level of clathrin heavy chain was found to be downregulated both at the mRNA and protein levels. The concomitant increase of dynamin and decrease of clathrin expression may be explained by the recent results from Iversen et al (2003) showing that a downregulation of clathrin induced an upregulation of dynamin in fibroblasts. These modulations resulted in an accumulation of clathrin-coated pits at the cell surface connected to the plasma membrane via long dynaminwrapped necks (Iversen et al, 2003). Taken together, these results suggest that chronic morphine treatment alters membrane and probably receptors trafficking in rat striatum.

Arc (activity-regulated cytoskeleton-associated protein) is classified as an immediate-early gene because of its rapid induction after stimulation. Chronic morphine produced a significant increase in the mRNA and protein levels of Arc in rat striatum. The modulation of this protein in different rat brain structures by several drugs of abuse has been previously described (Ammon et al, 2003; Fosnaugh et al, 1995; Freeman et al, 2002; Kodama et al, 1998; Tan et al, 2000). The exact function of Arc is unknown but its induction and localization in dendrites and soma (Steward and Worley, 2001; Wallace et al, 1998) led to the hypothesis of its involvement in cytoskeletal rearrangements during the process of synaptic plasticity (Lyford et al, 1995). Since Arc mRNA has a short half-life (Steward and Worley, 2001), the upregulation observed here is unlikely to result from a direct action of morphine, but rather from a long-term adaptation of the dendritic network. This supports the modification of dendritic branching observed following chronic morphine treatment (Robinson and Kolb, 1999).

Microtubules are cytoskeletal polymers of $\alpha / \beta$ tubulin heterodimers. They contribute to the formation, main- 
tenance, and function of axons and dendrites (review in Signor and Scholey, 2000). Expression of regulators of microtubule dynamics in rat striatum was found to be modified by chronic morphine treatment. Expression levels of $\alpha$-tubulin and Tau were significantly decreased both at the mRNA and protein levels. Tubulin polymerization is a highly dynamic process, implying that microtubules are constantly undergoing rapid transitions between growth to shrinkage states ('dynamic instability') (Mitchison and Kirschner, 1984). The dynamics and organization of microtubules are under the control of microtubule-associated proteins (MAPs) (review in Sayas et al, 2002). Tau proteins belong to the MAPs family, and favor the nucleation of new microtubules, reduce their dynamic instability, and stabilize them against depolymerizing agents (review in Billingsley and Kincaid, 1997). In vitro, the expression level of Tau proteins are decreased in the neuroblastoma cell line SH-SY5Y after $48 \mathrm{~h}$ treatment with morphine (Lew, 1997). This study presents the first evidence of Tau regulation by morphine in vivo. Conversely, microtubules can be destabilized by proteins such as stathmin (review in Cassimeris, 2002). The critical role of stathmin in the maintenance of axonal integrity has been demonstrated in stathmin-deficient mice (Liedtke et al, 2002). The downregulation of stathmin observed here represents the first report of its modulation by chronic morphine treatment in vivo. Taken together with the decrease in tubulin expression and the downregulation of a microtubule stabilizing factor (Tau), the decrease in stathmin expression suggests a disorganization of axonal cytoskeleton.

Another protein important for axonal elongation and plasticity is GAP-43. In this study, the expression of Gap43 was decreased at the mRNA level but increased at the protein level. This apparent discrepancy could be explained by the delay between mRNA modulation and protein regulation reported for this protein (Van der Zee et al, 1989). Gap43 is synthesized during outgrowth and regeneration at an increased rate and enriched in nerve growth cones (review in Skene, 1989). The upregulation of the protein observed here suggests enhanced sprouting activity after chronic morphine treatment.

Gfap is exclusively expressed in glial cells, where it represents the major intermediate filament protein (Eng and Ghirnikar, 1994). In this study, we observed an upregulation of Gfap both at the mRNA and the protein levels. An increase of Gfap in response to morphine in different brain regions has been reported by others: ventral tegmental area (Beitner-Johnson et al, 1993), spinal cord, and hippocampus (Song and Zhao, 2001). This enhanced expression of Gfap is also observed in the hippocampus of chronic heroin abusers (Buttner et al, 2000). An increase in Gfap is associated with astrogliosis in response to brain injury and is used as an indirect measure of neurotoxicity (review in Eng et al, 2000). Song and Zhao (2001) showed that the increase observed in Gfap levels after chronic morphine treatment could be attributed mainly to hypertrophy of astroglial cells. Moreover, they showed that glial cells are involved in morphine tolerance to analgesia. The increase of Gfap observed here confirms that this protein could be a marker of changes in neuron-glia signalling (Song and Zhao, 2001).
There is an increasing evidence that the expression and activity of cellular proteins are modified by chronic morphine administration. Adaptations in $\mathrm{G}$ proteins and cAMP system in numerous brain regions known to be involved in the classic effects of opiates, including the striatum, have been described (Kaewsuk et al, 2001; Matsuoka et al, 1994; Self et al, 1995; Selley et al, 1997). The modulation of transcription factors (CREB, $\Delta$ FosB) after chronic morphine treatment has been described (Lane Ladd et al, 1997; Maldonado et al, 1996). Several heat-shock proteins (hsp70, hsp40, hsp27 and hsp105) are upregulated in the frontal cortex of rats chronically treated with morphine (Ammon et al, 2003; Fan et al, 2002, 2003; Loguinov et al, 2001; Nestler et al, 2001). Our results showing an increase in the mRNA level of Arc and no change in that of actin are consistent with the results of Ammon et al. The present results also confirm the increase in dynamin protein level previously showed in the striatum of mice chronically treated with morphine (Noble et al, 2000).

The modifications of mRNA and proteins levels observed in this study are summarized in Table 2. We found significant regulation of several genes related to neuronal plasticity following chronic morphine treatment. Although we cannot exclude a contribution of mild withdrawal in the observed modifications, the differential expression of cytoskeletal genes supports and extends the previous studies showing morphological alteration of neurons (Sklair-Tavron et al, 1996) after chronic morphine treatment. Moreover, chronic opiate exposure decreases neurofilament proteins in rat and human brain (Beitner-Johnson et al, 1992; Beitner-Johnson and Nestler, 1993), which are not only implicated in axonal transport but are also responsible for maintaining the caliber of axons (review in Al-Chalabi and Miller, 2003). In addition to this, the altered regulation observed in this study suggests membrane trafficking impairment, microtubule disorganization, neuritogenesis, and dendritic activation following chonic morphine treatment. These alterations of nerve functioning could contribute to the modification of synaptic transmission and thus underlie neuroadaptations to chronic morphine administration and the associated long-lasting behavioral sensitization.

Table 2 Summary Table Showing the Modifications of mRNA and Protein Levels in the Striatum of Rats Chronically Treated with Morphine as Compared to Control Group

\begin{tabular}{lcc}
\hline Gene & mRNA & Protein \\
\hline Arc & $\nearrow\left(1.48^{*}\right)$ & $\nearrow\left(2.33^{* *}\right)$ \\
Gap43 & $\searrow(0.7 * *)$ & $\nearrow\left(1.3^{* *}\right)$ \\
-Tubulin & $\searrow(0.64 *)$ & $\searrow\left(0.73^{* *}\right)$ \\
Stathmin & $\searrow\left(0.65^{* *}\right)$ & $\searrow(0.77 * *)$ \\
Cltc & $\searrow\left(\left.0.7\right|^{*}\right)$ & $\searrow(0.7 * * *)$ \\
Dynamin-1 & $\leftrightarrow$ & $\nearrow(1.97 * *)$ \\
Gfap & $\nearrow\left(\left.1.4\right|^{*}\right)$ & $\nearrow(1.77 * *)$ \\
Tau & $\searrow(0.7 * *)$ & $\searrow(0.6 * *)$ \\
\hline
\end{tabular}

The numbers in parentheses represent the fold change. $* P<0.05$, $* * P<0.01$, **** $P<0.00$ I (Student's test) 


\section{REFERENCES}

Al-Chalabi A, Miller CC (2003). Neurofilaments and neurological disease. BioEssays 25: 346-355.

Ammon S, Mayer P, Riechert U, Tischmeyer H, Hollt V (2003). Microarray analysis of genes expressed in the frontal cortex of rats chronically treated with morphine and after naloxone precipitated withdrawal. Mol Brain Res 112: 113-125.

Bacci A, Verderio C, Pravettoni E, Matteoli M (1999). The role of glial cells in synaptic function. Philos Trans R Soc London B Biol Sci 354: 403-409.

Bassareo V, Tanda G, Di Chiara G (1995). Increase of extracellular dopamine in the medial prefrontal cortex during spontaneous and naloxone-precipitated opiate abstinence. Psychopharmacology (Berl) 122: 202-205.

Beitner-Johnson D, Guitart X, Nestler EJ (1992). Neurofilament proteins and the mesolimbic dopamine system: common regulation by chronic morphine and chronic cocaine in the rat ventral tegmental area. J Neurosci 12: 2165-2176.

Beitner-Johnson D, Guitart X, Nestler EJ (1993). Glial fibrillary acidic protein and the mesolimbic dopamine system: regulation by chronic morphine and Lewis-Fischer strain differences in the rat ventral tegmental area. J Neurochem 61: 1766-1773.

Beitner-Johnson D, Nestler EJ (1993). Chronic morphine impairs axoplasmic transport in the rat mesolimbic dopamine system. Neuroreport 5: 57-60.

Bieche I, Nogues C, Paradis V, Olivi M, Bedossa P, Lidereau R et al (2000). Quantitation of hTERT gene expression in sporadic breast tumors with a real-time reverse transcription-polymerase chain reaction assay. Clin Cancer Res 6: 452-459.

Billingsley ML, Kincaid RL (1997). Regulated phosphorylation and dephosphorylation of tau protein: effects on microtubule interaction, intracellular trafficking and neurodegeneration. Biochem J 323: 577-591.

Buttner A, Mall G, Penning R, Weis S (2000). The neuropathology of heroin abuse. Forensic Sci Int 113: 435-442.

Cassimeris L (2002). The oncoprotein 18/stathmin family of microtubule destabilizers. Curr Opin Cell Biol 14: 18-24.

Crippens D, Robinson TE (1994). Withdrawal from morphine or amphetamine: different effects on dopamine in the ventralmedial striatum studied with microdialysis. Brain Res 650: 56-62.

Diana M, Pistis M, Muntoni A, Gessa G (1995). Profound decrease of mesolimbic dopaminergic neuronal activity in morphine withdrawn rats. J Pharmacol Exp Ther 272: 781-785.

Eng LF, Ghirnikar RS (1994). GFAP and astrogliosis. Brain Pathol 4: 229-237.

Eng LF, Ghirnikar RS, Lee YL (2000). Glial fibrillary acidic protein: GFAP-thirty-one years (1969-2000). Neurochem Res 25: 1439-1451.

Erdtmann-Vourliotis M, Mayer P, Riechert U, Grecksch G, Hollt V (1998). Identification of brain regions that are markedly activated by morphine in tolerant but not in naive rats. Brain Res Mol Brain Res 61: 51-61.

Fan X, Zhang J, Zhang X, Yue W, Ma L (2002). Acute and chronic morphine treatments and morphine withdrawal differentially regulate GRK2 and GRK5 gene expression in rat brain. Neuropharmacology 43: 809-816.

Fan XL, Zhang JS, Zhang XQ, Yue W, Ma L (2003). Differential regulation of [beta]-arrestin 1 and [beta]-arrestin 2 gene expression in rat brain by morphine. Neuroscience 117: 383-389.

Ferrer-Alcon M, Garcia-Sevilla JA, Jaquet PE, La Harpe R, Riederer $\mathrm{BM}$, Walzer C et al (2000). Regulation of nonphosphorylated and phosphorylated forms of neurofilament proteins in the prefrontal cortex of human opioid addicts. J Neurosci Res 61: 338-349.

Fosnaugh JS, Bhat RV, Yamagata K, Worley PF, Baraban JM (1995). Activation of arc, a putative 'effector' immediate early gene, by cocaine in rat brain. $J$ Neurochem 64: 2377-2380.
Freeman WM, Brebner K, Lynch WJ, Patel KM, Robertson DJ, Roberts DC et al (2002). Changes in rat frontal cortex gene expression following chronic cocaine. Brain Res Mol Brain Res 104: $11-20$.

Garcia-Sevilla JA, Ventayol P, Busquets X, La Harpe R, Walzer C, Guimon J (1997). Marked decrease of immunolabelled $68 \mathrm{kDa}$ neurofilament (NF-L) proteins in brains of opiate addicts. Neuroreport 8: 1561-1565.

Iversen TG, Skretting G, Van Deurs B, Sandvig K (2003). From the cover: clathrin-coated pits with long, dynamin-wrapped necks upon expression of a clathrin antisense RNA. Proc Natl Acad Sci USA 100: 5175-5180.

Kaewsuk S, Hutamekalin P, Ketterman AJ, Khotchabhakdi N, Govitrapong P, Casalotti SO (2001). Morphine induces shortlived changes in G-protein gene expression in rat prefrontal cortex. Eur J Pharmacol 411: 11-16.

Kelz MB, Chen J, Carlezon Jr WA, Whisler K, Gilden L, Beckmann $\mathrm{AM}$ et al (1999). Expression of the transcription factor deltaFosB in the brain controls sensitivity to cocaine. Nature 401: 272-276.

Kodama M, Akiyama K, Ujike H, Shimizu Y, Tanaka Y, Kuroda S (1998). A robust increase in expression of arc gene, an effector immediate early gene, in the rat brain after acute and chronic methamphetamine administration. Brain Res 796: 273-283.

Lane Ladd SB, Pineda J, Boundy VA, Pfeuffer T, Krupinski J, Aghajanian GK et al (1997). CREB (cAMP response elementbinding protein) in the locus coeruleus: biochemical, physiological, and behavioral evidence for a role in opiate dependence. J Neurosci 17: 7890-7901.

Lew GM (1997). Changes in microtubular tau protein after morphine in a cultured human neuroblastoma cell line. Gen Pharmacol 29: 869-872.

Liedtke W, Leman EE, Fyffe RE, Raine CS, Schubart UK (2002). Stathmin-deficient mice develop an age-dependent axonopathy of the central and peripheral nervous systems. Am J Pathol 160: 469-480.

Loguinov AV, Anderson LM, Crosby GJ, Yukhananov RY (2001). Gene expression following acute morphine administration. Physiol Genom 6: 169-181.

Lyford GL, Yamagata K, Kaufmann WE, Barnes CA, Sanders LK, Copeland NG et al (1995). Arc, a growth factor and activityregulated gene, encodes a novel cytoskeleton-associated protein that is enriched in neuronal dendrites. Neuron 14: 433-445.

Maisonneuve IM, Rossman KL, Keller Jr RW, Glick SD (1992). Acute and prolonged effects of ibogaine on brain dopamine metabolism and morphine-induced locomotor activity in rats. Brain Res 575: 69-73.

Maldonado R, Blendy JA, Tzavara E, Gass P, Roques BP, Hanoune J et al (1996). Reduction of morphine abstinence in mice with a mutation in the gene encoding CREB. Science 273: 657-659.

Matsuoka I, Maldonado R, Defer N, Noel F, Hanoune J, Roques BP (1994). Chronic morphine administration causes region-specific increase of brain type VIII adenylyl cyclase mRNA. Eur $J$ Pharmacol 268: 215-221.

Mitchison T, Kirschner M (1984). Microtubule assembly nucleated by isolated centrosomes. Nature 312: 232-237.

Nestler EJ, Aghajanian GK (1997). Molecular and cellular basis of addiction. Science 278: 58-63.

Nestler EJ, Barrot M, Self DW (2001). DeltaFosB: a sustained molecular switch for addiction. Proc Natl Acad Sci USA 98: 11042-11046.

Noble F, Szucs M, Kieffer B, Roques BP (2000). Overexpression of dynamin is induced by chronic stimulation of mu- but not deltaopioid receptors: relationships with mu-related morphine dependence. Mol Pharmacol 58: 159-166.

Pezawas LM, Fischer G, Diamant K, Schneider C, Schindler SD, Thurnher M et al (1998). Cerebral CT findings in male opioiddependent patients: stereological, planimetric and linear measurements. Psychiatry Res 83: 139-147. 
Pozzi L, Trabace L, Invernizzi R, Samanin R (1995). Intranigral GR-113808, a selective 5-HT4 receptor antagonist, attenuates morphine-stimulated dopamine release in the rat striatum. Brain Res 692: 265-268.

Przewlocka B, Lason W, Przewlocki R (1994). The effect of chronic morphine and cocaine administration on the Gs and Go protein messenger RNA levels in the rat hippocampus. Neuroscience 63: 1111-1116.

Robinson TE, Kolb B (1999). Morphine alters the structure of neurons in the nucleus accumbens and neocortex of rats. Synapse 33: 160-162.

Ruiz F, Fournie-Zaluski MC, Roques BP, Maldonado R (1996). Similar decrease in spontaneous morphine abstinence by methadone and RB 101, an inhibitor of enkephalin catabolism. Br J Pharmacol 119: 174-182.

Sayas CL, Avila J, Wandosell F (2002). Regulation of neuronal cytoskeleton by lysophosphatidic acid: role of GSK-3. Biochim Biophys Acta 1582: 144-153.

Self DW, McClenahan AW, Beitner-Johnson D, Terwilliger RZ, Nestler EJ (1995). Biochemical adaptations in the mesolimbic dopamine system in response to heroin self-administration. Synapse 21: 312-318.

Selley DE, Nestler EJ, Breivogel CS, Childers SR (1997). Opioid receptor-coupled G-proteins in rat locus coeruleus membranes: decrease in activity after chronic morphine treatment. Brain Res 746: $10-18$.

Sever S (2002). Dynamin and endocytosis. Curr Opin Cell Biol 14: 463-467.

Signor D, Scholey JM (2000). Microtubule-based transport along axons, dendrites and axonemes. Essays Biochem 35: 89-102.
Skene JH (1989). Axonal growth-associated proteins. Annu Rev Neurosci 12: 127-156.

Sklair-Tavron L, Shi WX, Lane SB, Harris HW, Bunney BS, Nestler EJ (1996). Chronic morphine induces visible changes in the morphology of mesolimbic dopamine neurons. Proc Natl Acad Sci USA 93: 11202-11207.

Song P, Zhao ZQ (2001). The involvement of glial cells in the development of morphine tolerance. Neurosci Res 39: 281-286.

Steward O, Worley PF (2001). A cellular mechanism for targeting newly synthesized mRNAs to synaptic sites on dendrites. Proc Natl Acad Sci USA 98: 7062-7068.

Tan A, Moratalla R, Lyford GL, Worley P, Graybiel AM (2000). The activity-regulated cytoskeletal-associated protein arc is expressed in different striosome-matrix patterns following exposure to amphetamine and cocaine. J Neurochem 74: 20742078.

Tirumalai PS, Howells RD (1994). Regulation of calbindin-D28K gene expression in response to acute and chronic morphine administration. Brain Res Mol Brain Res 23: 144-150.

Van der Zee CE, Nielander HB, Vos JP, Lopes da Silva S, Verhaagen J, Oestreicher AB et al (1989). Expression of growthassociated protein B-50 (GAP43) in dorsal root ganglia and sciatic nerve during regenerative sprouting. J Neurosci 9: 3505-3512.

Walker JM, Thompson LA, Frascella J, Friederich MW (1987). Opposite effects of mu and kappa opiates on the firing-rate of dopamine cells in the substantia nigra of the rat. Eur J Pharmacol 134: 53-59.

Wallace CS, Lyford GL, Worley PF, Steward O (1998). Differential intracellular sorting of immediate early gene mRNAs depends on signals in the mRNA sequence. J Neurosci 18: 26-35. 